\title{
A systematic review of surgical procedures on thoracic myelopathy
}

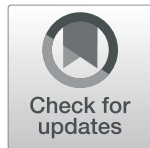

Shiqi Zhu, Yu Wang, Peng Yin ${ }^{*}$ and Qingjun Su*i

\begin{abstract}
Purpose: The surgical treatment of thoracic myelopathy is still controversial and also a challenge for spine surgeons. Therefore, the objective of this study was to review the related literature on the surgical treatment of thoracic myelopathy and try to define treatment guidelines for spine surgeons on thoracic myelopathy.

Methods: Relevant literatures were searched based on the PubMed, EMBASE, and Cochrane Library between January 2008 and December 2018. Some data on the characteristics of patients were extracted, including number of patients, mean age, surgical procedures, blood loss, complications, and pre-/post-operation modified JOA score. Recovery rate was used to assess the effect of surgery outcome, and the safety was evaluated by blood loss and incidence of complications.

Results: Thirty-five studies met the inclusion criteria and were retrieved. A total of 2183 patients were included in our systematic review, with the average age of 55.2 years. There were $69.8 \%$ patients diagnosed as ossification of ligamentum flavum (OLF), 20.0\% as ossification of posterior longitudinal ligament (OPLL), 9.3\% as disk herniation (DH), and 0.9\% as others including diffuse idiopathic skeletal hyperostosis (DISH) and ankylosing spondylitis (AS). The volume of blood loss was more in the treatment of circumferential decompression (CD) than posterior decompression (PD), and the incidence of complications was higher in CD $(P<0.05)$. The volume of blood loss in minimally invasive surgery (MIS) was lowest and the incidence of complications was $19.2 \%$. Post-operation recovery rate was 0.49 in PD, 0.35 in $C D$, and 0.29 in MIS while the recovery rate was 0.54 in PD, 0.55 in CD, and 0.49 in MIS at the last followup. When focusing on the OLF specifically, incidence of complications in PD was much lower than CD, with less blood loss and higher recovery rate. Focusing on the OPLL specifically, incidence of complications in PD was much lower than $C D$, with less blood loss while there was no statistical difference in recovery rate between these two methods.
\end{abstract}

Conclusions: This systematic review showed that posterior decompression for thoracic myelopathy is safer and better than circumferential decompression according to the complication rate and surgical outcome. And we should also consider the location of compression before the operation.

Keywords: Thoracic spine stenosis (TSS), Thoracic myelopathy (TM), Ossification of posterior longitudinal ligament (OPLL), Ossification of ligamentum flavum (OLF), Thoracic spine decompression

\footnotetext{
*Correspondence: yinpeng3904@126.com; qjsurex@sohu.com

Departmen of Orthopedics, Capital Medical University Affiliated Beijing

Chaoyang Hospital, Capital Medical University, NO.8 Gongtinanlu, Beijing

100020, People's Republic of China
}

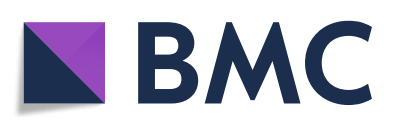

(c) The Author(s). 2020 Open Access This article is licensed under a Creative Commons Attribution 4.0 International License, which permits use, sharing, adaptation, distribution and reproduction in any medium or format, as long as you give appropriate credit to the original author(s) and the source, provide a link to the Creative Commons licence, and indicate if changes were made. The images or other third party material in this article are included in the article's Creative Commons licence, unless indicated otherwise in a credit line to the material. If material is not included in the article's Creative Commons licence and your intended use is not permitted by statutory regulation or exceeds the permitted use, you will need to obtain permission directly from the copyright holder. To view a copy of this licence, visit http://creativecommons.org/licenses/by/4.0/ The Creative Commons Public Domain Dedication waiver (http://creativecommons.org/publicdomain/zero/1.0/) applies to the data made available in this article, unless otherwise stated in a credit line to the data. 


\section{Background}

The incidence of thoracic myelopathy is relatively lower among spine myelopathy, which is mainly caused by $\mathrm{DH}$, OPLL, OLF, and others (DISH and AS). It has been reported that thoracic spine stenosis due to OPLL or OLF is the major etiology of thoracic myelopathy [1].

Patients with thoracic myelopathy always company with the symptoms of motor and sensory function reduction of lower limbs, and these symptoms often could not be relieved by conservative treatments, so surgical treatment gradually become the standard treatment for patients with thoracic myelopathy. However, the optimal surgical procedure is still controversial [2]. Posterior decompression and circumferential decompression through posterior approach were mostly applied on thoracic spine surgery, because nearby structures, such as aorta and esophagus, may be injured or damaged by anterior approach, and then the fatal complications might be encountered [3]. In recent years, minimally invasive surgery was preferred by some surgeons on the treatment of single lesion type of thoracic myelopathy, but the technique of the surgery was demanding $[4,5]$. Although there are many surgical options up to now, there has not been a guideline or review to assist surgeons to choose a proper surgical approach for specific patient yet because of the complex etiologies and challenging surgical approach. Hence, in our following systematic review, we gathered the characteristics data of patients with thoracic myelopathy and compared the effect and safety of outcomes among these three surgical procedures (posterior decompressive, circumferential decompression through posterior approach, and minimally invasive surgery) and tried to give a valuable reference for surgeons to choose the optimal treatment for each patient with thoracic myelopathy.

\section{Methods}

\section{Search strategy}

Relevant literature searches were performed via PubMed, EMBASE, and Cochrane Library between January 1, 2008, and December 31, 2018. Keywords used to identify relevant studies were "thoracic spine stenosis," "thoracic myelopathy," "ossification of posterior longitudinal ligament," and "ossification of ligamentum flavum."

\section{Eligibility criteria}

Eligibility criteria for article selection were as follows: (1) population: 10 more patients with thoracic myelopathy; (2) intervention: posterior decompression, circumferential decompression, or minimally invasive surgery; (3) outcome: motor and sensory function evaluated by modified JOA score; (4) study type: prospective or retrospective case series; and (5) full-text published articles between January 1, 2008, and December 31, 2018, and available in English.

\section{Date collection}

All relevant data that met eligibility criteria were independently extracted by two authors, and the disagreements were resolved by discussion with each other. The following information was extracted from each article: (1) first author, (2) publish year, (3) patient's demographics, (4) characteristics of thoracic myelopathy, (5) surgical approach, (6) preoperative and postoperative modified JOA score (mJOA), and (7) complications. Modified Japanese Orthopedic Association Scoring System (mJOA score) were applied to assess the motor and sensory function of patient and recovery rate (RR) for surgical outcomes. The recovery rate was calculated as:

$\mathrm{RR}=($ postoperative mJOA score - preoperative mJOA score $)$
$/(11-$ preoperative mJOA score $) * \times 100 \%$

There were amount of surgical procedures used to decompress the thoracic spine cord mostly through posterior approach. Therefore, we categorized the different techniques into three major procedures: (1) posterior decompression (PD); (2) circumferential decompression (CD), vertebra fused or not; and (3) minimally invasive surgery (MIS) where decompression of thoracic spine was given through a posterior minimally invasive way. This nomenclature was based on the differences in decompression mechanisms among the various techniques.

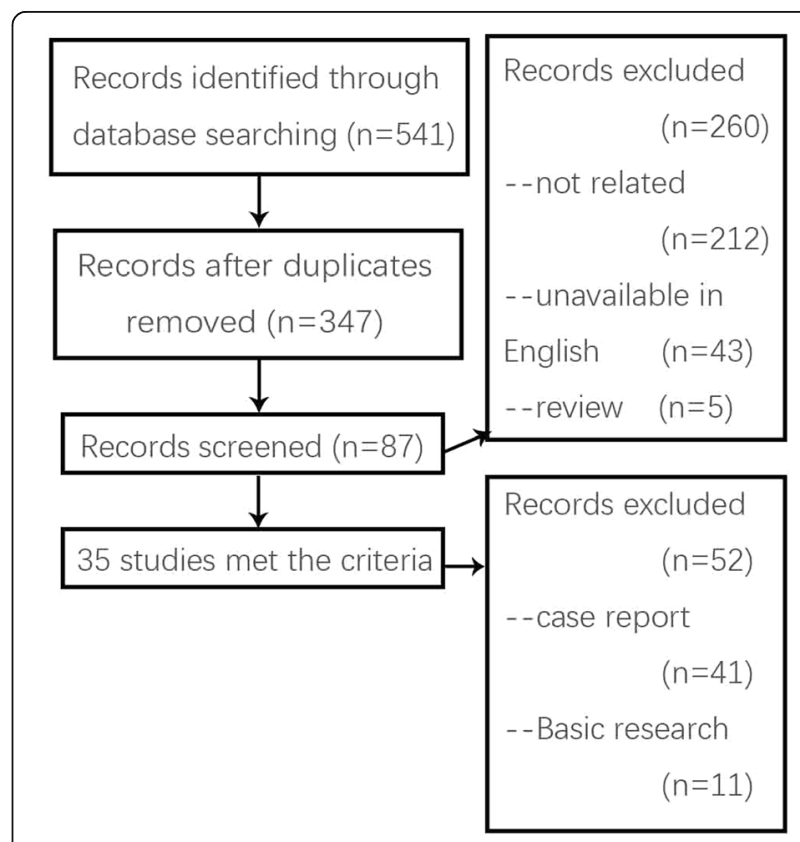

Fig. 1 Flow chart illustrating number of studies evaluated at each stage in the systematic review 
Table 1 Characteristics of included studies

\begin{tabular}{|c|c|c|c|c|c|c|c|c|c|c|c|c|c|}
\hline \multirow[t]{2}{*}{ Author } & \multirow{2}{*}{$\begin{array}{l}\text { Study } \\
\text { NO. }\end{array}$} & \multirow{2}{*}{$\begin{array}{l}\text { Number } \\
\text { of } \\
\text { patient }\end{array}$} & \multirow{2}{*}{$\begin{array}{l}\text { Gender } \\
\text { ratio } \\
\text { (male/ } \\
\text { female) }\end{array}$} & \multirow{2}{*}{$\begin{array}{l}\text { Mean } \\
\text { age } \\
\text { (years) }\end{array}$} & \multirow{2}{*}{$\begin{array}{l}\text { Mean } \\
\text { follow- } \\
\text { up dur- } \\
\text { ation } \\
\text { (months) }\end{array}$} & \multirow{2}{*}{ Cause of TM } & \multirow[t]{2}{*}{ Comorbidity } & \multicolumn{3}{|c|}{ Type of OPLL/OLF } & \multicolumn{3}{|c|}{ Severe lesions } \\
\hline & & & & & & & & Single & $\begin{array}{l}\text { Multiple } \\
\text { but not } \\
\text { fusion }\end{array}$ & Fusion & $\begin{array}{l}\text { T1- } \\
\text { T5 }\end{array}$ & $\begin{array}{l}\text { T5- } \\
\text { T9 }\end{array}$ & $\begin{array}{l}\text { T9- } \\
\text { TL1 }\end{array}$ \\
\hline Wang et al. & 1 & 33 & 1.20 & 55.03 & 70.82 & OLF & $\begin{array}{l}\mathrm{DM} 2+\mathrm{CM} \\
2+\mathrm{LM} 11\end{array}$ & 16 & & & 9 & 4 & 52 \\
\hline Wang et al. & 2 & 18 & 0.38 & 56.2 & 31.2 & OLF & DO 11 & 5 & 0 & 13 & 1 & 6 & 33 \\
\hline Li et al. & 3 & 85 & 0.57 & 60.2 & 49.2 & OLF & DM 9 & & & & 22 & 19 & 44 \\
\hline Hou et al. & 4 & 427 & 1.42 & 53 & & $\begin{array}{l}\text { OLF } 309+\text { OPLL } 120 \\
+ \text { DH } 129\end{array}$ & $\begin{array}{l}\text { CM } 61+L M \\
47\end{array}$ & & & & & & \\
\hline Onishi et al. & 5 & 73 & 1.70 & 61.9 & 70.2 & $\begin{array}{l}\text { OLF } 55+\text { OPLL } 25+ \\
\text { DH } 8\end{array}$ & DM16 & & & & 11 & 18 & 44 \\
\hline $\begin{array}{l}\text { Hitchon } \\
\text { et al. }\end{array}$ & 6 & 44 & 2.14 & 66 & 16 & & $\begin{array}{l}\text { CM } 13+L M \\
6\end{array}$ & & & & & & \\
\hline \multirow[t]{2}{*}{$\begin{array}{l}\text { Uehara } \\
\text { et al. }\end{array}$} & 7 & 35 & 1.91 & 70.5 & 44 & $\begin{array}{l}\text { OLF } 20+\text { OPLL } 6+ \\
\text { DH } 1\end{array}$ & & & & & 4 & 1 & 30 \\
\hline & & 15 & 1.50 & 63.5 & 46.1 & $\begin{array}{l}\text { OLF } 5+\text { OPLL } 4+ \\
\text { DH } 3+\text { AS } 3\end{array}$ & & & & & 0 & 1 & 14 \\
\hline Yang et al. & 8 & 21 & 0.90 & 52.1 & 24.5 & OPLL & & 11 & 3 & 7 & 27 & 11 & 3 \\
\hline Onishi et al. & 9 & 15 & 0.87 & 65.5 & 45 & OLF $15+$ OPLL 15 & DM 4 & & & & 3 & 10 & 2 \\
\hline \multirow[t]{2}{*}{ Wang et al. } & \multirow[t]{2}{*}{10} & 23 & \multirow[t]{2}{*}{0.84} & \multirow{2}{*}{\multicolumn{2}{|c|}{39.8}} & \multirow{2}{*}{$\begin{array}{l}\text { OLF } 99+\text { OPLL } 66+ \\
\text { DH } 17\end{array}$} & & & & & & & \\
\hline & & 145 & & & & & & & & & & & \\
\hline Li et al. & 11 & 11 & 0.57 & 50.2 & 21.2 & OLF $11+$ OPLL 9 & DO 8 & & & & 19 & 22 & 24 \\
\hline He et al. & 12 & 283 & 1.62 & 51.8 & & $\begin{array}{l}\text { OLF } 123 \text { + OPLL } 73 \\
\text { + DH } 54 \text { + DISH } 19\end{array}$ & & & & & 49 & 60 & 174 \\
\hline Ma et al. & 13 & 23 & 1.55 & 34.7 & 4.6 & & DO 5 & & & & & & \\
\hline $\begin{array}{l}\text { Kawaguchi } \\
\text { et al. }\end{array}$ & 14 & 41 & 3.10 & 59.4 & 66 & OLF & DM 11 & & & & & & \\
\hline Yang et al. & 15 & 38 & 1.37 & 59 & 46.1 & OLF & & 6 & 32 & & & 23 & 13 \\
\hline Nie et al. & 16 & 18 & 0.80 & 56.3 & 35 & OLF & DO 2 & & 18 & & & & \\
\hline Liu et al. & 17 & 13 & 0.62 & 56 & 36.8 & OLF $13+$ OPLL 13 & DO 2 & & & & & & \\
\hline Li et al. & 18 & 19 & 0.58 & 55.3 & 53.2 & OLF & DM 2 & & & & & & \\
\hline \multirow[t]{2}{*}{ Yu et al. } & 19 & 78 & 2.25 & 59.6 & & OLF & & 63 & 15 & & & 22 & \\
\hline & & & & & & & & & & & & & 15 \\
\hline Gao et al. & 20 & 75 & 1.34 & 54.7 & 35.7 & OLF & $\begin{array}{l}\text { CM } 12+L M \\
7\end{array}$ & & 75 & & & & \\
\hline \multirow[t]{3}{*}{ Li et al. } & \multirow[t]{3}{*}{21} & 7 & 0.75 & 56.7 & 74.4 & OL 31F + OPLL 31 & & & & & & & \\
\hline & & 11 & 0.83 & 56.8 & 52.8 & & & & & & & & \\
\hline & & 13 & 0.44 & 57.3 & 90.2 & & & & & & & & \\
\hline Sun et al. & 22 & 266 & 1.37 & 54.3 & & OLF & DO 67 & & & & & & \\
\hline $\begin{array}{l}\text { Yamazaki } \\
\text { et al. }\end{array}$ & 23 & 24 & 0.41 & 54.8 & 53 & OPLL & & & & & & & \\
\hline Zhang et al. & 24 & 11 & 2.66 & 54.5 & & OLF 11 + OPLL 11 & CM 1 & & & & & & \\
\hline Chen et al. & 25 & 16 & 1.66 & 57.5 & 57.3 & OLF & CM $1+$ LM 2 & & & & 4 & 4 & 21 \\
\hline $\begin{array}{l}\text { Matsuyama } \\
\text { et al. }\end{array}$ & 26 & 37 & & 58 & & OPLL & & & & & & & \\
\hline Hur et al. & 27 & 26 & 1.88 & 53 & 27.3 & OLF & & 1 & 5 & 20 & 10 & 6 & 25 \\
\hline $\begin{array}{l}\text { Zhong } \\
\text { et al. }\end{array}$ & 28 & 22 & 1.00 & 52.4 & 35.6 & OLF & CM $4+$ LM 3 & 3 & 8 & 11 & 2 & 1 & 14 \\
\hline Yoon et al. & 29 & 40 & 1.85 & 57.08 & 17.3 & & & & & & & & \\
\hline
\end{tabular}


Table 1 Characteristics of included studies (Continued)

\begin{tabular}{|c|c|c|c|c|c|c|c|c|c|c|c|c|c|}
\hline \multirow[t]{2}{*}{ Author } & \multirow{2}{*}{$\begin{array}{l}\text { Study } \\
\text { NO. }\end{array}$} & \multirow{2}{*}{$\begin{array}{l}\text { Number } \\
\text { of } \\
\text { patient }\end{array}$} & \multirow{2}{*}{$\begin{array}{l}\text { Gender } \\
\text { ratio } \\
\text { (male/ } \\
\text { female) }\end{array}$} & \multirow{2}{*}{$\begin{array}{l}\text { Mean } \\
\text { age } \\
\text { (years) }\end{array}$} & \multirow{2}{*}{$\begin{array}{l}\text { Mean } \\
\text { follow- } \\
\text { up dur- } \\
\text { ation } \\
\text { (months) }\end{array}$} & \multirow[t]{2}{*}{ Cause of TM } & \multirow[t]{2}{*}{ Comorbidity } & \multicolumn{3}{|c|}{ Type of OPLL/OLF } & \multicolumn{3}{|c|}{ Severe lesions } \\
\hline & & & & & & & & Single & $\begin{array}{l}\text { Multiple } \\
\text { but not } \\
\text { fusion }\end{array}$ & Fusion & $\begin{array}{l}\text { T1- } \\
\text { T5 }\end{array}$ & $\begin{array}{l}\text { T5- } \\
\text { T9 }\end{array}$ & $\begin{array}{l}\text { T9- } \\
\text { TL1 }\end{array}$ \\
\hline Park et al. & 30 & 12 & 0.50 & 60.5 & 24.2 & OLF & & 10 & 2 & & & & \\
\hline Zhao et al. & 31 & 13 & 1.16 & & 13.3 & OLF & & & & & & & \\
\hline \multirow[t]{2}{*}{ Zhang et al. } & \multirow[t]{2}{*}{32} & 56 & 2.29 & & \multirow[t]{2}{*}{24} & \multirow[t]{2}{*}{ OLF } & \multirow{2}{*}{$\begin{array}{l}\text { DM } 23+\text { DO } \\
48\end{array}$} & 33 & 23 & & & 4 & 3 \\
\hline & & 40 & 2.07 & & & & & 20 & 29 & & & 3 & 5 \\
\hline $\begin{array}{l}\text { Hirabayashi } \\
\text { et al. }\end{array}$ & 33 & 13 & 3.33 & 58 & & OLF & & & & & & & \\
\hline $\begin{array}{l}\text { Takahata } \\
\text { et al. }\end{array}$ & 34 & 30 & 0.66 & 53 & 96 & OLF & CM 15 & & & & & & \\
\hline Khoo et al. & 35 & 13 & 0.63 & 51.8 & 12 & $\mathrm{DH}$ & & & & & & & \\
\hline
\end{tabular}

The blanks are not mentioned in the study

$D M$ diabetes mellitus, DP dura ossification, $C M$ cervical myelopathy, $L M$ lumbar myelopathy

\section{Statistical analysis}

The statistical differences among surgical procedures were analyzed by chi-square test and $t$ test, and the statistical significance was determined when $P<0.05$. All the relative data was analyzed by the SPSS Statistical Software version 19.0 (SPSS Inc., Chicago, IL, USA).

\section{Results}

\section{Literature search}

The initial literature search identified 541 records while 87 articles were identified as related articles on thoracic myelopathy. Ultimately, 35 studies met the inclusion criteria by reviewing the full-text articles (Fig. 1) which contained 5 retrospective comparative studies [6-10] and 30 case series $[2,4,5,11-37]$ (Table 1 ).

\section{Study details}

A total of 2170 patients were included in our systematic review. $56.9 \%$ of patients were male, and $43.1 \%$ were female. The average age of patients was 55.2 years, and the mean follow-up ranged from 13.3 months to 96 months, and 43.0 months in total.

\section{Characteristics of thoracic myelopathy}

Within all the patients, there were $69.8 \%$ patients diagnosed as OLF, $20.0 \%$ as OPLL, $9.3 \%$ as DH, and others including DISH and AS. There were some comorbidities in patients with thoracic myelopathy, including $18.5 \%$ with diabetes mellitus (67 in 362), 15.3\% with cervical myelopathy (102 in 667), 19.9\% with lumbar myelopathy (133 in 667), and $32.1 \%$ with ossified dura matter (143 in 445). In all of the OPLL and OLF, $40.0 \%$ were single lesion type (168 in 420), 47.9\% were multiple but nonfusion type (201 in 420) and 12.1\% were fusion type (51 in 420). Besides, in all spine stenosis lesions, upper thoracic lesions (T1-T4) represented 19.9\% (213 in 1070), middle thoracic lesions (T5-T8) represented 18.6\% (199 in 1070), and lower thoracic lesions (T9-L1) represented $61.5 \%$ (658 in 1070).

\section{Surgical procedures}

We categorized all the surgical procedures for thoracic myelopathy into three major procedures: (1) posterior decompression, (2) circumferential decompression, and (3) minimally invasive surgery. However, it is a pity that only two study applied minimally invasive surgery on 26 patients suffered from single lesion type OLF, and the number of patients is too small to come up with a statistical difference between minimally invasive surgery and other surgery approach. Therefore, we mainly focused on the differences between PD and CD.

Mostly, surgeons determine surgical approach according to the compression location and etiologies. Causes of thoracic myelopathy and surgical approach were reported in 27 studies; there were 1102 OLF lesions treated by PD and 61 by CD and 222 OPLL lesions treated by PD and 52 by CD. Patients with disc herniation were all treated by $\mathrm{PD}$. The statistical results showed that posterior decompression was more performed for OLF and circumferential decompression was more applied for OPLL $(p<0.01)$.

We found that the volume of blood loss was more in CD than PD $(p<0.01)$, and there was no statistical difference in vertebral fusion amount and operation time $(p>0.05)$. Predictably, the blood loss and operation time were both extremely low in minimally invasive surgery.

As for the complications, there were 231 cases in 1311 PD (17.62\%) patients and 48 cases in $81 \mathrm{CD}(59.26 \%)$ patients, where the dural tear and leakage of CSF were the major complications. The incidence of complications was lower in PD than CD $(p<0.01)$. Besides, it is remarkable that the incidence of immediately neurologic 


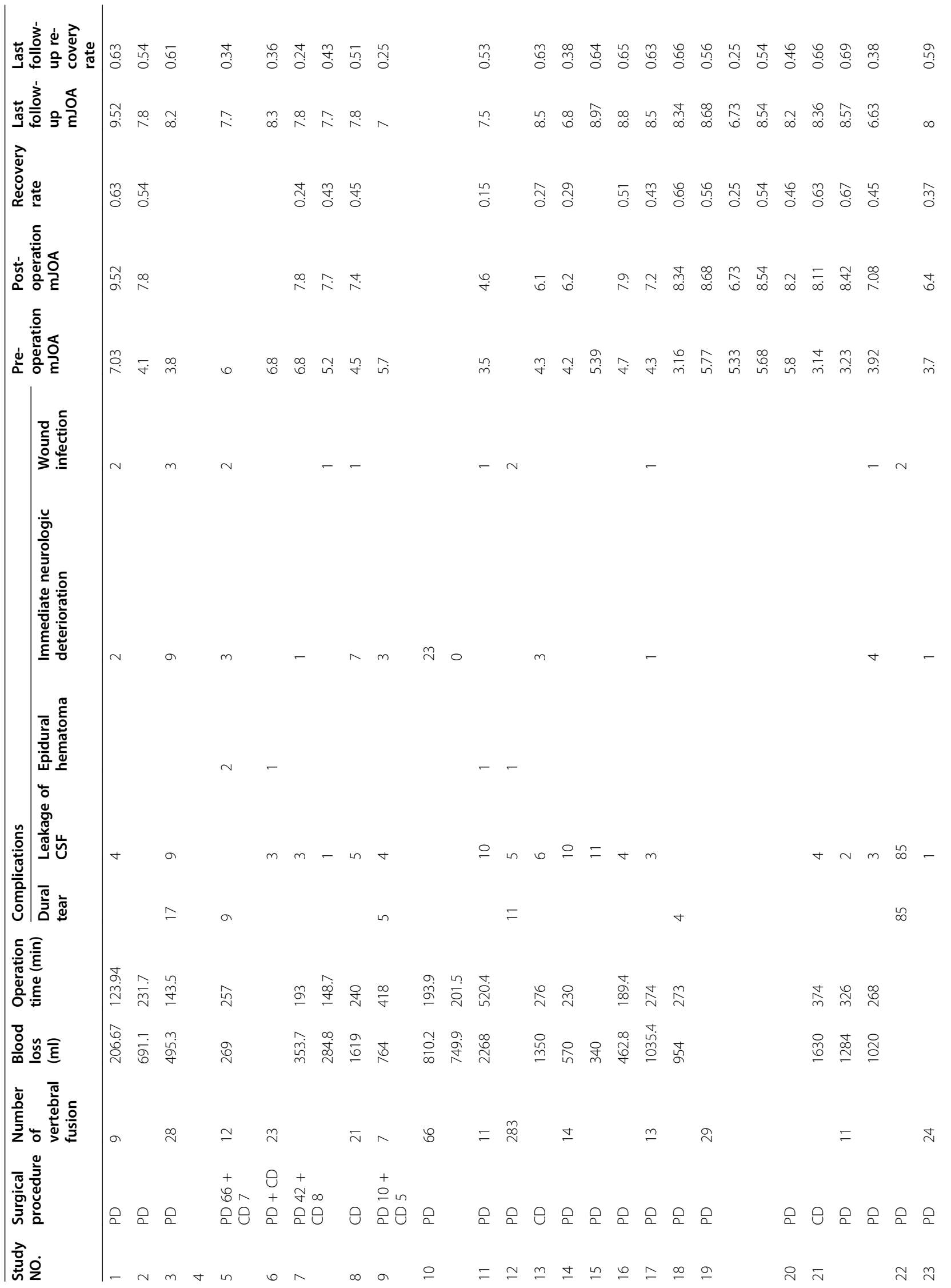




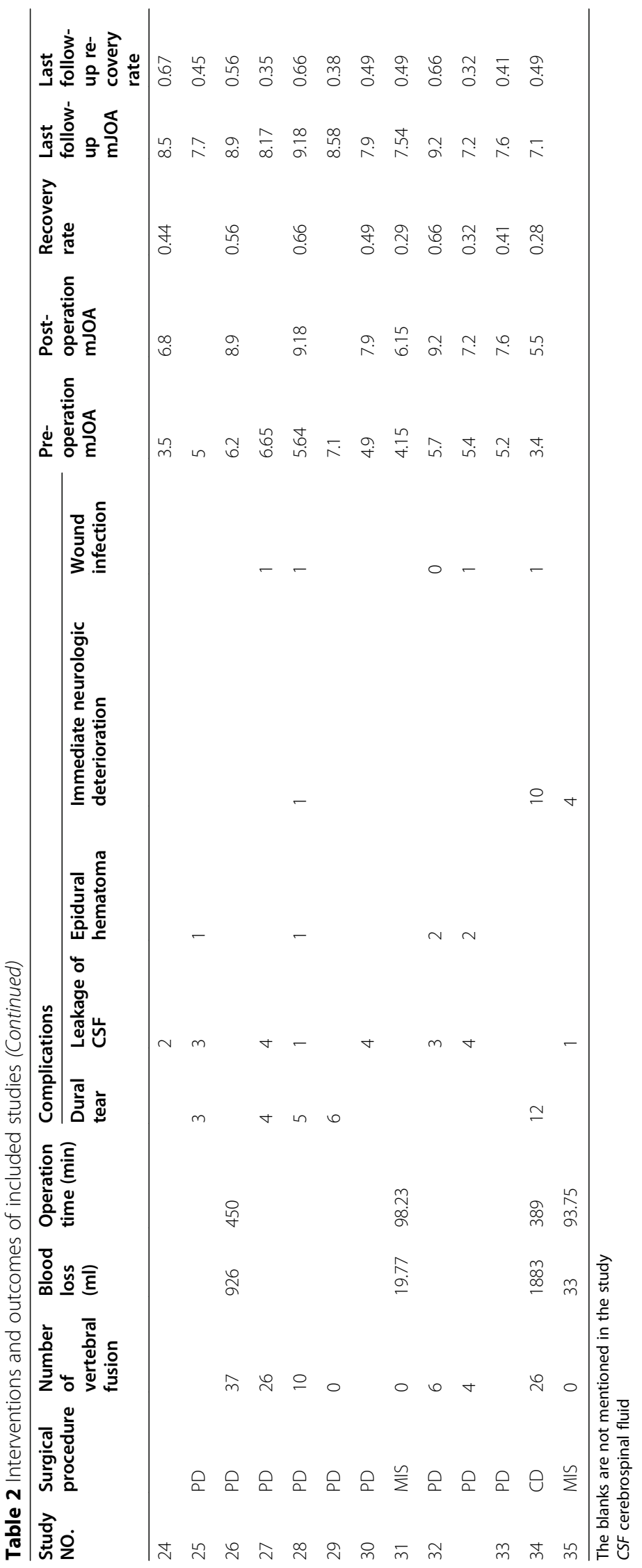


Table 3 Comparison of relative data among three surgical approaches

\begin{tabular}{llllllllll}
\hline $\begin{array}{l}\text { Surgical } \\
\text { procedure }\end{array}$ & $\begin{array}{l}\text { Epidural } \\
\text { hematoma }\end{array}$ & $\begin{array}{l}\text { Immediate neurologic } \\
\text { deterioration }\end{array}$ & $\begin{array}{l}\text { Wound } \\
\text { infection }\end{array}$ & $\begin{array}{l}\text { Incidence of } \\
\text { complications }\end{array}$ & $\begin{array}{l}\text { Pre- } \\
\text { mJOA }\end{array}$ & $\begin{array}{l}\text { post- } \\
\text { mJOA }\end{array}$ & $\begin{array}{l}\text { Post- } \\
\text { recovery } \\
\text { rate }\end{array}$ & $\begin{array}{l}\text { Last } \\
\text { mJOA }\end{array}$ & $\begin{array}{l}\text { Last } \\
\text { recovery } \\
\text { rate }\end{array}$ \\
\hline PD & 6 & 6 & 6 & $17.62 \%$ & 5.22 & 8.07 & 0.49 & 8.32 & 0.54 \\
CD & 0 & 20 & 1 & $59.26 \%$ & 3.92 & 6.39 & 0.35 & 7.79 & 0.55 \\
MIS & 0 & 4 & 0 & $19.2 \%$ & 4.15 & 6.15 & 0.29 & 7.54 & 0.49 \\
\hline
\end{tabular}

deterioration in $\mathrm{CD}$ was extremely higher than PD. Lastly, the incidence of complications in minimally invasive surgery was $19.8 \%$.

\section{Outcomes of surgery}

The mJOA score ranged from 3.14 to 7.03 before surgery and averaged in 5.27, while ranged from 4.60 to 9.52 after surgery and averaged in 7.80. Besides, the post-operation recovery rate ranged from 0.15 to 0.67 and averaged in 0.46. In the last follow-up, the mJOA score ranged from 6.63 to 9.52 and averaged in 8.18, while the recovery rate ranged from 0.24 to 0.69 and averaged in 0.51 (Table 2). When comparing the PD and $\mathrm{CD}$, the average postoperation $\mathrm{RR}$ was 0.49 in $\mathrm{PD}$ and 0.35 in $C D$, while the average last follow-up $R R$ was 0.54 in $\mathrm{PD}$ and 0.55 in $\mathrm{CD}$, which mean that the short-term outcome of PD was better than $\mathrm{CD}$ while there was no statistical difference in long-term outcome (Table 3). Interestingly, we could find that surgeons chosen $\mathrm{CD}$ because of the poor mJOA score before surgery, which mean that a poor RR of CD is predictable after the surgery. As for the MIS, the RR was 0.29 after operation and 0.49 in the last follow-up. When focus on the OLF separately, incidence of complications in PD was much lower than $C D$, with less blood loss and the higher recovery rate (Table 4). In OPLL, incidence of complications in PD was much lower than $\mathrm{CD}$ with less blood loss, but there was no statistical difference in recovery rate. Although the blood loss and the incidence of complications in patients with minimally invasive surgery was comparatively low, the short-term outcome was unsatisfactory.

\section{Discussion}

In this systematic review, we analyzed the safety and effect of each surgical procedure for patients with thoracic myelopathy, and a number of characteristics on patients with thoracic myelopathy were provided in our study. Besides, the difference between PD and CD for OPLL or OLF was separately analyzed. To our best knowledge, this is the first systematic review to analyze the difference between PD and CD for patients with OPLL or OLF. Our results showed that PD was better than CD for patients with OLF according to the safety and effect of each procedures, and PD was safer than CD for patients with OPLL

In 35 retrospective case series, $56.9 \%$ patients were male and $43.1 \%$ were female which stated that thoracic myelopathy may prefer a male population, which was contrary to a systematic review about thoracic OPLL [38]. The inconsistence was mainly caused by different target patients, because the major cause of thoracic myelopathy was OLF (69.8\%). Meanwhile, we found that the incidence of diabetes mellitus was $18.5 \%$ in thoracic myelopathy patients which was much higher than general population $(8.3 \%$ in 2013$)$. It stated that diabetes mellitus may be related with thoracic myelopathy somehow.

It was reported that local mechanical stress could accelerate the ossification procedure [39]. Chen et al. hypothesized that the unstable circumstance in spine myelopathy may cause an ossification of other lesion ligament [40]. In this systematic review, the coincidence of cervical and lumbar myelopathy was $15.3 \%$ and $19.9 \%$, which was much less than the ratio in a study [6]. However, these statistics could not definitely support this

Table 4 Comparison of PD and CD for patients with OLF or OPLL

\begin{tabular}{|c|c|c|c|c|c|c|c|c|c|}
\hline & $\begin{array}{l}\text { Patient } \\
\text { amount }\end{array}$ & $\begin{array}{l}\text { Incidence of } \\
\text { complications }\end{array}$ & $\begin{array}{l}\text { Blood loss } \\
(\mathrm{ml})\end{array}$ & $\begin{array}{l}\text { Operation time } \\
\text { (min) }\end{array}$ & $\begin{array}{l}\text { Pre- } \\
\text { mJOA }\end{array}$ & $\begin{array}{l}\text { Post- } \\
\text { mJOA }\end{array}$ & $\begin{array}{l}\text { Post-recovery } \\
\text { rate }\end{array}$ & $\begin{array}{l}\text { Last } \\
\text { mJOA }\end{array}$ & $\begin{array}{l}\text { Last recovery } \\
\text { rate }\end{array}$ \\
\hline $\begin{array}{l}\text { PD for } \\
\text { OLF }\end{array}$ & 680 & $34.6 \%$ & 492.5 & 179.8 & 5.40 & 8.34 & 0.525 & 8.41 & 0.538 \\
\hline $\begin{array}{l}\text { CD for } \\
\text { OLF }\end{array}$ & 30 & $76.7 \%$ & 1883 & 389 & 3.4 & 5.5 & 0.28 & 7.1 & 0.49 \\
\hline $\begin{array}{l}\text { PD for } \\
\text { OPLL }\end{array}$ & 61 & $8.3 \%$ & 926 & 450 & 5.22 & 7.92 & 0.467 & 8.54 & 0.574 \\
\hline $\begin{array}{l}\text { CD for } \\
\text { OPLL }\end{array}$ & 21 & $61.9 \%$ & 1619 & 240 & 4.5 & 7.4 & 0.45 & 7.8 & 0.51 \\
\hline
\end{tabular}


hypothesis because the causality between thoracic myelopathy and cervical/lumbar myelopathy remains unclear. Dural ossification happened in $32.1 \%$ patients because severe OLF and OPLL often came up with adhesion between dura matter and ossified ligament. Lastly, thoracic myelopathy in low lesions (T9-L1) happened in major (61.5\%).

In the past 10 years, the surgical technique of PD or $\mathrm{CD}$ was improved, so the technique was a little bit different among all studies. For example, there were laminectomy [12], laminoplasty, foraminotomy, and others called posterior decompression while there was a minor difference among them. In this systematic review, we categorized the surgical procedures for thoracic myelopathy into three: PD, CD, and MIS. Unfortunately, only 2 studies reported minimally invasive surgery and it only reported 26 cases, so we mainly compared the differences between PD and CD. Up to now, surgeons chose surgical procedures mainly according to the location of myelopathy.

It was reported that the indication of circumferential decompression is localized spinal cord compression by a large OPLL in the kyphotic curve [41]. However, there was not an indication applied by surgeons strictly. So the indication cannot be analyzed in this systematic review.

We found that the volume of blood loss was more in CD than PD $(p<0.01)$, and there was no statistical difference in vertebral fusion amount and operation time $(p>0.05)$. When considering the difference in blood loss, we could not ignore that $\mathrm{CD}$ is an extra anterior decompression compared to $\mathrm{PD}$, so the incision was larger in CD than PD. Besides, the blood loss and operation time were both extremely low in MIS. The main reason for these was that the surgery is only managing a single lesion $[4,5]$. The incidence of complications was $17.62 \%$ in $\mathrm{PD}, 59.26 \%$ in $\mathrm{CD}$, and $19.2 \%$ in MIS. However, it was remarkable that the incidence of immediately neurologic deterioration in $\mathrm{CD}$ was extremely high. It may be anterior decompression or resection of adhesion between dura matter and ossified ligament through posterior approach often caused damage on the spine cord and nerve root [37]. To decrease the incidence of complications, some surgeons suggested a technique that we should keep a floating fragment adherent to the dura matter [26], but the kind of decompression was not satisfactory when compared with a complete decompression. There was another strategy that increasing the mean arterial pressure could prevent the neurologic deterioration, because Wang et al. found that mean arterial pressure less than $81 \mathrm{mmHg}$ was one of risk factors [7]. Besides, to release the immediately neurologic deterioration, glucocorticoid was suggested to ease the inflammation after surgery.
As for the outcomes of surgery, postoperation recovery rate was 0.49 in PD, 0.35 in $\mathrm{CD}$, and 0.29 in MIS while at last follow-up, the recovery rate was 0.54 in PD, 0.55 in $\mathrm{CD}$, and 0.49 in MIS. Therefore, the short-term outcome of PD was much better than CD and MIS but there was no statistical difference on the long-term outcomes. It is remarkable that mJOA score of CD before surgery is poorer, which mean that surgeons preferred $\mathrm{CD}$ for severe thoracic myelopathy and this may result in a poorer recovery rate than PD. Indeed, the principle on treating spinal pathology is to approach the pathology as much as possible. However, in Li's article, surgeons have chosen PD and CD for patients who had similar mJOA score before surgery while there was no difference on RR after surgery [9]. His results showed that PD has a same efficacy as CD for severe thoracic myelopathy. In summary, our results in the systematic review showed that PD was safer and better for patients with thoracic myelopathy than $\mathrm{CD}$. Besides, the safety of MIS was satisfactory while the outcome was not, which might be because of the unaggressive surgeons.

We also analyzed the difference between PD and CD for patients with OPLL or OLF. According to the outcome from 20 articles, PD was safer than $C D$ whether OLF or OPLL, and the outcome of surgery in PD was much better than CD for OLF but nearly same for OPLL. Therefore, when choosing the surgical procedures for patients with OPLL or OLF, PD was suggested. Because there was no such a study of $\mathrm{DH}$ independently and the morbidity of thoracic DH is much lower than OLF/OPLL, we did not analyze the difference between $\mathrm{PD}$ and CD for thoracic DH.

This systematic review has some limitations. Firstly, there was no prospective research and only 5 retrospective cohort research. Secondly, there were only 2 articles about MIS included and the number of patients was too poor to come up with a statistical significance. Thirdly, the severity of thoracic myelopathy was not discussed in articles included.

\section{Conclusion}

This systematic review showed that posterior decompression for thoracic myelopathy is safer and better than circumferential decompression according to the complication rate and surgical outcome. And we should also consider the location of compression before the operation.

\section{Abbreviations \\ OLF: Ossification of ligamentum flavum; OPLL: Ossification of posterior longitudinal ligament; DH: Disk herniation; DISH: Diffuse idiopathic skeletal hyperostosis; AS: Ankylosing spondylitis; CD: Circumferential decompression; PD: Posterior decompression; MIS: Minimally invasive surgery; mJOA score: Modified Japanese Orthopedic Association Scoring System}

Acknowledgements

We would like to thank all the participants in the studies. 


\section{Authors' contributions}

Shiqi Zhu and Peng Yin contributed to the writing of the paper and drafting of the manuscript. Peng Yin and Qingjun Su contributed to the study design. Yu Wang and Shiqi Zhu collected and analyzed the data. Peng Yin reviewed and edited the manuscript. All authors read and approved the final manuscript.

\section{Funding}

None.

\section{Availability of data and materials}

All data used and analyzed during this study are available from the corresponding author upon reasonable request.

\section{Ethics approval and consent to participate}

This research was not associated with any ethics problems.

\section{Consent for publication}

Written informed consent for publication of their clinical details and/or clinical images was obtained from the included articles.

\section{Competing interests}

The authors declare that they have no competing interests.

Received: 7 August 2019 Accepted: 10 November 2020

Published online: 10 December 2020

\section{References}

1. Ahn DK, Lee S, Moon SH, Boo KH, Chang BK, Lee Jl. Ossification of the ligamentum flavum. Asian Spine J. 2014;8:89. https://doi.org/10.4184/asj. 2014.8.1.89.

2. He B, Yan L, Xu Z, Guo H, Liu T, Hao D. Treatment strategies for the surgical complications of thoracic spinal stenosis: a retrospective analysis of two hundred and eighty three cases. Int Orthop. 2014;38:117-22. https:/doi.org/ 10.1007/s00264-013-2103-2.

3. Min JH, Jang JS, Lee SH. Clinical results of ossification of the posterior longitudinal ligament (OPLL) of the thoracic spine treated by anterior decompression. J Spinal Disord Tech. 2008;21:116-9. https://doi.org/10.1097/ BSD.0b013e318060091a.

4. Zhao W, Shen C, Cai R, Wu J, Zhuang Y (2017) Minimally invasive surgery for resection of ossification of the ligamentum flavum in the thoracic spine. Neurosurgery.

5. Khoo LT, Smith ZA, Asgarzadie F, Barlas Y, Armin SS, Tashjian V, et al, Minimally invasive extracavitary approach for thoracic discectomy and interbody fusion: 1-year clinical and radiographic outcomes in 13 patients compared with a cohort of traditional anterior transthoracic approaches. J Neurosurg Spine. 2011;14:250.

6. Uehara M, Tsutsumimoto T, Yui M, Ohta H, Ohba H, Misawa H. Single-stage surgery for compressive thoracic myelopathy associated with compressive cervical myelopathy and/or lumbar spinal canal stenosis. Eur Spine J. 2016; 25:1904-11. https://doi.org/10.1007/s00586-015-4133-5.

7. Wang $H, M a L$, Xue R, Yang D, Wang T, Wang Y, et al. The incidence and risk factors of postoperative neurological deterioration after posterior decompression with or without instrumented fusion for thoracic myelopathy. Medicine (Baltimore). 2016;95:e5519. https://doi.org/10.1097/ MD.0000000000005519.

8. Yu S, Wu D, Li F, Hou T. Surgical results and prognostic factors for thoracic myelopathy caused by ossification of ligamentum flavum: posterior surgery by laminectomy. Acta Neurochir. 2013;155:1169-77. https://doi.org/10.1007/ s00701-013-1694-0.

9. Li M, Meng H, Du J, Tao H, Luo Z, Wang Z. Management of thoracic myelopathy caused by ossification of the posterior longitudinal ligament combined with ossification of the ligamentum flavum-a retrospective study. Spine J. 2012;12:1093-102. https://doi.org/10.1016/j.spinee.2012.10.022.

10. Zhang J, Wang L, Li J, Yang P, Shen Y. Predictors of surgical outcome in thoracic ossification of the ligamentum flavum: focusing on the quantitative signal intensity. Sci Rep-Uk. 2016;6. https://doi.org/10.1038/srep23019.

11. Wang H, Wei F, Long H, Han G, Sribastav SS, Li Z, et al. Surgical outcome of thoracic myelopathy caused by ossification of ligamentum flavum. J Clin Neurosci. 2017;45:83-8. https://doi.org/10.1016/j.jocn.2017.07.008.
12. Wang T, Yin C, Wang D, Li S, Chen X. Surgical technique for decompression of severe thoracic myelopathy due to tuberous ossification of ligamentum flavum. Clin Spine Surg. 2017;30:E7-E12. https://doi.org/10.1097/BSD. 0000000000000213

13. Li Z, Ren D, Zhao Y, Hou S, Li L, Yu S, et al. Clinical characteristics and surgical outcome of thoracic myelopathy caused by ossification of the ligamentum flavum: a retrospective analysis of 85 cases. Spinal Cord. 2016; 54:188-96. https://doi.org/10.1038/sc.2015.139.

14. Hou X, Sun C, Liu X, Liu Z, Qi Q, Guo Z, et al. Clinical features of thoracic spinal stenosis-associated myelopathy: a retrospective analysis of 427 cases. Clin Spine Surg. 2016;29:86-9. https://doi.org/10.1097/BSD. 0000000000000081.

15. Onishi E, Yasuda T, Yamamoto H, Iwaki K, Ota S. Outcomes of surgical treatment for thoracic myelopathy: a single-institutional study of 73 patients. Spine (Phila Pa 1976). 2016;41:E1356-63. https://doi.org/10.1097/ BRS.0000000000001622.

16. Hitchon PW, Abode-lyamah K, Dahdaleh NS, Grossbach AJ, El TN, Noeller J, et al. Risk factors and outcomes in thoracic stenosis with myelopathy: a single center experience. Clin Neurol Neurosurg. 2016;147:84-9. https://doi. org/10.1016/j.clineuro.2016.05.029.

17. Yang B, Wang Y, He X, Li H. Treatment for thoracic ossification of posterior longitudinal ligament with posterior circumferential decompression: complications and managements. J Orthop Surg Res. 2016;11. https://doi. org/10.1186/s13018-016-0489-4.

18. Onishi E, Sano H, Matsushita M. Surgical treatment for thoracic myelopathy due to simultaneous ossification of the posterior longitudinal ligament and ligamentum flavum at the same level. Clin Spine Surg. 2016;29:E389-95. https://doi.org/10.1097/BSD.0000000000000059.

19. Li W, Guo S, Sun Z, Zhao Y. Multilevel thoracic ossification of ligamentum flavum coexisted with/without lumbar spinal stenosis: staged surgical strategy and clinical outcomes. BMC Musculoskel Dis. 2015:16. https://doi. org/10.1186/s12891-015-0672-5.

20. Ma X, An HS, Zhang Y, Brown NM, Chen Z, Zhang G, et al. A radical procedure of circumferential spinal cord decompression through a modified posterior approach for thoracic myelopathy caused by severely impinging anterior ossification. Spine J. 2014;14:651-8. https://doi.org/10.1016/j.spinee. 2013.06.091.

21. Kawaguchi $Y$, Yasuda T, Seki S, Nakano M, Kanamori M, Sumi S, et al. Variables affecting postsurgical prognosis of thoracic myelopathy caused by ossification of the ligamentum flavum. Spine J. 2013;13:1095-107. https:// doi.org/10.1016/j.spinee.2013.03.001.

22. Yang Z, Xue Y, Dai Q, Zhang C, Zhou HF, Pan JF, et al. Upper facet joint en bloc resection for the treatment of thoracic myelopathy caused by ossification of the ligamentum flavum. J Neurosurg Spine. 2013;19:81-9. https://doi.org/10.3171/2013.4.SPINE12345.

23. Nie ZH, Liu FJ, Shen Y, Ding WY, Wang LF. Lamina osteotomy and replantation with miniplate fixation for thoracic myelopathy due to ossification of the ligamentum flavum. Orthopedics. 2013;36:e353-9. https:// doi.org/10.3928/01477447-20130222-26.

24. Liu FJ, Chai Y, Shen Y, Xu JX, Du W, Zhang P. Posterior decompression with transforaminal interbody fusion for thoracic myelopathy due to ossification of the posterior longitudinal ligament and the ligamentum flavum at the same level. J Clin Neurosci. 2013;20:570-5. https://doi.org/10.1016/j.jocn. 2012.04.016

25. Li M, Wang Z, Du J, Luo Z, Wang Z. Thoracic myelopathy caused by ossification of the ligamentum flavum: a retrospective study in Chinese patients. J Spinal Disord Tech. 2013;26:E35-40. https://doi.org/10.1097/BSD Ob013e31827ada68.

26. Gao R, Yuan W, Yang L, Shi G, Jia L. Clinical features and surgical outcomes of patients with thoracic myelopathy caused by multilevel ossification of the ligamentum flavum. Spine J. 2013;13:1032-8. https://doi.org/10.1016/j. spinee.2013.02.034.

27. Sun X, Sun C, Liu X, Liu Z, Qi Q, Guo Z, et al. The frequency and treatment of dural tears and cerebrospinal fluid leakage in 266 patients with thoracic myelopathy caused by ossification of the ligamentum flavum. Spine (Phila Pa 1976). 2012;37:E702-7. https://doi.org/10.1097/ BRS.0b013e31824586a8.

28. Yamazaki M, Okawa A, Fujiyoshi T, Furuya T, Koda M. Posterior decompression with instrumented fusion for thoracic myelopathy caused by ossification of the posterior longitudinal ligament. Eur Spine J. 2010;19: 691-8. https://doi.org/10.1007/s00586-009-1266-4. 
29. Zhang HQ, Chen LQ, Liu SH, Zhao D, Guo CF. Posterior decompression with kyphosis correction for thoracic myelopathy due to ossification of the ligamentum flavum and ossification of the posterior longitudinal ligament at the same level. J Neurosurg Spine. 2010;13:116-22. https://doi.org/10. 3171/2010.3.SPINE09237.

30. Chen $X Q$, Yang HL, Wang GL, Gu Y, Pan WM, Dong RB, et al. Surgery for thoracic myelopathy caused by ossification of the ligamentum flavum. J Clin Neurosci. 2009;16:1316-20. https://doi.org/10.1016/j.jocn.2008.12.025.

31. Matsuyama Y, Sakai Y, Katayama Y, Imagama S, Ito Z, Wakao N, et al. Indirect posterior decompression with corrective fusion for ossification of the posterior longitudinal ligament of the thoracic spine: is it possible to predict the surgical results? Eur Spine J. 2009;18:943-8. https://doi.org/10.1007/ s00586-009-0956-2

32. Hur H, Lee J, Lee J, Kim J, Kim S. Thoracic myelopathy caused by ossification of the ligamentum flavum. J Korean Neurosurg S. 2009:46:189. https://doi. org/10.3340/jkns.2009.46.3.189.

33. Zhong ZM, Wu Q, Meng TT, Zhu YJ, Qu DB. Clinical outcomes after decompressive laminectomy for symptomatic ossification of ligamentum flavum at the thoracic spine. J Clin Neurosci. 2016. https://doi.org/10.1016/j. jocn.2015.09.023.

34. Sang HY, Kim WH, Chung SB, Yong JJ, Park KW. Clinical analysis of thoracic ossified ligamentum flavum without ventral compressive lesion. Eur Spine J. 2011. https://doi.org/10.1007/s00586-010-1515-6.

35. Dong AP, Kim SW, Lee SM, Chong GK, Jang SJ (2012) Symptomatic myelopathy caused by ossification of the yellow ligament. Korean I Spine.

36. Hirabayashi H, Ebara S, Takahashi J, Narasaki K, Takahara K, Murakami G, et al. Surgery for thoracic myelopathy caused by ossification of the ligamentum flavum. Surg Neurol. 2008;69(114-116):116. https://doi.org/10. 1016/j.surneu.2007.01.045.

37. Takahata M, Ito M, Abumi K, Kotani Y, Sudo H, Minami A. Clinical results and complications of circumferential spinal cord decompression through a single posterior approach for thoracic myelopathy caused by ossification of posterior longitudinal ligament. Spine (Phila Pa 1976). 2008;33:1199-208. https://doi.org/10.1097/BRS.0b013e3181714515.

38. Xu N, Yu M, Liu X, Sun C, Chen Z, Liu Z. A systematic review of complications in thoracic spine surgery for ossification of the posterior longitudinal ligament. Eur Spine J. 2017;26:1803-9. https://doi.org/10.1007/ s00586-015-4097-5.

39. Kaneyama S, Doita M, Nishida K, Shimomura T, Maeno K, Tamura Y, et al. Thoracic myelopathy due to ossification of the yellow ligament in young baseball pitchers. J Spinal Disord Tech. 2008;21:68-71. https://doi.org/10. 1097/BSD.0b013e31811dfc2d.

40. Chen Y (2008) Ossification of ligamentum flavum related to thoracic kyphosis after tuberculosis. Spine.

41. Kato S, Murakami H, Demura S, Yoshioka K, Yokogawa N, Takaki S, et al. Indication for anterior spinal cord decompression via a posterolateral approach for the treatment of ossification of the posterior longitudinal ligament in the thoracic spine: a prospective cohort study. Eur Spine J. 2019. https://doi.org/10.1007/s00586-019-06047-5.

\section{Publisher's Note}

Springer Nature remains neutral with regard to jurisdictional claims in published maps and institutional affiliations.

Ready to submit your research? Choose BMC and benefit from:

- fast, convenient online submission

- thorough peer review by experienced researchers in your field

- rapid publication on acceptance

- support for research data, including large and complex data types

- gold Open Access which fosters wider collaboration and increased citations

- maximum visibility for your research: over $100 \mathrm{M}$ website views per year

At BMC, research is always in progress.

Learn more biomedcentral.com/submissions 